\title{
Na contramão do discurso midiático: uma perspectiva garantista da atuação do delegado ou da delegada de polícia
}

\author{
Against midiatic speech: a guarantistic \\ perspective of the police chief's role
}

\begin{abstract}
Soraia da Rosa Mendes ${ }^{1}$
Pós-Doutoranda Universidade Federal do Rio de Janeiro - Rio de Janeiro/RJ Doutora UnB. Professora IDP e UniCeub - Brasília/DF professorasoraiadarosamendes@gmail.com

lattes.cnpq.br/6101794465780378

orcid.org/0000-0002-6188-9216

Patrícia Tiraboschi Burin ${ }^{2}$

Mestranda no Instituto Brasiliense de Direito Público - Brasília/DF

patriciaburin@hotmail.com

lattes.cnpq.br/9586074659716337

orcid.org/0000-0002-4171-1568
\end{abstract}

RESUMO: Observado o interesse geral pelas ações policiais, em especial pelas prisões realizadas, parece natural que o jornalismo investigativo, se valendo da liberdade constitucional de imprensa, pretenda divulgar os resultados das suas operações. Partindo

1 Pós-doutoranda em Teorias Jurídicas Contemporâneas pela Universidade Federal do Rio de Janeiro - UFRJ. Doutora em Direito pela Universidade de Brasília - UnB. Mestre em Ciência Política pela Universidade Federal do Rio Grande do Sul. Especialista em Direitos Humanos pelo CESUSC/IFIBe. Professora do PPG Mestrado em Direito do Instituto Brasiliense de Direito Público - IDP, Professora de Direito Penal Centro Universitário de Brasília UniCeub. Pesquisadora líder dos Grupos de Pesquisa Sistema Penal e Garantias Fundamentais (CNPq-IDP). Membro da Associação Internacional de Direito Penal - AIDP.

2 Mestranda pelo IDP - Brasília/DF, pesquisadora do Grupos de Pesquisa Sistema Penal e Garantias Fundamentais (CNPq-IDP), assessora jurídica no STJ. 
da constatação da prática policial de expor à mídia o desviante detido logo após a sua captura, transformando este momento processual num espetáculo nem sempre admissível, e considerando os seus direitos e garantias constitucionais, especialmente a dignidade da pessoa humana, a presunção de inocência e os direitos de imagem (que não lhe são restringidos nem mesmo com a condenação definitiva), este artigo pretende, com base em pesquisa doutrinária, refletir a respeito da postura a ser adotada pela autoridade policial nessa situação. Questiona-se se há alguma circunstância em que a exposição do desviante detido é justificável. A hipótese é que cabe à autoridade policial resguardar a imagem daquele desviante detido, a menos que sua exposição seja necessária à investigação criminal.

PALAVRAS-CHAVE: ações policiais; prisões; espetaculização; liberdade de imprensa; garantias fundamentais; dignidade da pessoa humana; autoridade policial.

ABSTRACT: Regarded the general interest for the police actions, specially the arrests, its seems natural that the media, acknowledging its freedom, intends to broadcast the operation's results. Considering the police's praxis of exposing the arrested soon after the capture, transforming this procedure into a not always admissible spectacle, and considering the constitutional rights of the person arrested, specially his/her dignity, the presumption of innocence and his/her privacy rights (which are not restricted not even when condemned definitely), this article aims to discuss, based upon doctrinaire studies, how should the police authority act in such cases. It questions if there is any circumstance in which it is admissible to expose the arrested's image to the media. The hypothesis is that the police must protect the privacy of the arrested person, unless its exposure is necessary for the success of the investigation.

KEY-WORDS: police actions; arrests; spectacles; freedom of press; fundamental guaranties; human dignity; police authority.

SUMÁRIO: Introdução. 1. Garantias Relacionadas à Persecução Penal no Estado Democrático de Direito. 2. A Liberdade de Informação Jornalística e o Discurso Midiático. 3. O Papel da Autoridade Policial. Conclusão. Referências Bibliográficas. 


\section{INTRODUÇÃO}

A sensação de risco constante e de insegurança é algo arraigado no inconsciente coletivo. Vivemos um estado de pânico moral instituído, reivindicador da assunção de uma postura cada vez mais defensiva que, como sói acontecer, menos se reveste de reclamos genuínos por justiça, do que se assemelha ao desejo de vingança contra "aqueles que nos tiram a paz". Como certa vez dito pelo Ministro Marco Aurélio Mello, em entrevista ao programa Roda Viva da TV Cultura ${ }^{3}$, a população quer "vísceras e sangue", e, no embalo de discursos punitivistas, questiona a todo tempo o porquê de "os bandidos terem tantos direitos" e "a polícia não fazer nada".

O combate à criminalidade é, então, tema discutido diuturnamente, não só em conversas corriqueiras ou de especialistas, assim como também toma espaço privilegiado nos programas de televisão e rádio. Como pondera Benoni Belli o "tema da criminalidade desperta tanto interesse que foi alçado à condição de fonte inesgotável de inspiração para a indústria cinematográfica e seriados de TV de grande popularidade, além, é claro, dos programas policiais"5.

3 O programa foi veiculado aos 19 de outubro de 2015. O Ministro se referia à operação Lava Jato quando pontuou: "Dá-se uma ênfase muito grande ao anseio popular, mas a população, de início consideradas as imputações e desvios de conduta, ela quer vísceras, ela quer sangue e o Judiciário não pode atender a esse anseio da população”. O texto foi retirado da notícia a respeito do programa, veiculada online pelo Estado de São Paulo. Disponível em: <http://politica.estadao.com.br/blogs/fausto-macedo/a-populacao-quer-visceras-quer-sangue-diz-marco-aurelio-sobre-a-lava-jato/>. Acesso em: 02 mai. 2017.

4 Infelizmente, como já advertiu Loïc Wacquant tratando especificamente do Brasil, as duas décadas de ditadura militar continuam a pesar bastante tanto sobre o funcionamento do Estado como sobre as mentalidades coletivas, o que faz com que o conjunto das classes sociais tendam a identificar a defesa dos direitos do homem com a tolerância à 'bandidagem': WACQUANT, Loïc. As prisões da Miséria. Rio de Janeiro: Jorge Zahar, 2001, p. 10.

5 BELLI, Benoni. Tolerância Zero e Democracia no Brasil: visões da segurança pública na década de 90. São Paulo: Perspectiva, 2004. p. xi. 
A mídia ${ }^{6}$, a quem a Constituição Federal de 1988 garantiu a liberdade de informação jornalística ${ }^{7}$, decorrente da liberdade de expressão, arvora-se representar os anseios de uma população que vive amedrontada, tendo no discurso do medo um de seus produtos mais lucrativos $^{8}$. E, ao explorar um certo anseio popular punitivista/vingativo, em última instância o incentiva.

Basta que liguemos a televisão em horários improváveis, como o do almoço, para termos acesso a detalhes chocantes dos crimes do dia.

6 Não desconhecemos que as discussões acerca da objetividade e subjetividade no jornalismo, tal como nos lembra Felipe Pena (Teoria do jornalismo. São Paulo: Contexto, 2005, p. 50-51.), ao afirmar que quando o público e os jornalistas percebem que os textos são influenciados pela subjetividade e podem distorcer a realidade - até mesmo por força do inconsciente, como demonstrou Freud - o mundo está em plena crise do sistema democrático. Tampouco que "a cupidez induziu a mídia desregulamentada a concentrar-se em apenas duas de suas funções: entretenimento e publicidade", como ensina Claud-Jean Bertrand ( $O$ arsenal da democracia: sistemas de responsabilização da mídia. Bauru: EDUSC, 2002, p. 18). Neste estudo, todavia, no qual o objeto não é especificamente a discussão acerca das definições conceituais de jornalismo, liberdade de expressão ou liberdade de imprensa, o termo "mídia" será utilizado como sinônimo de jornalismo investigativo, cujo trabalho é divulgado nos jornais, na internet, mas sobretudo na televisão. Partimos, pois, do pressuposto de que a civilização do espetáculo, com sua intensa valorização do entretenimento, as imagens prevalecem sobre as ideias, privilegiando esses meios de comunicação embasados no audiovisual (LLOSA, Mario Vargas. A civilização do espetáculo. Uma radiografia do nosso tempo e da nossa cultura. Rio de Janeiro: Objetiva, 2013. p. 29 e 41).

7 Art. 220. A manifestação do pensamento, a criação, a expressão e a informação, sob qualquer forma, processo ou veículo não sofrerão qualquer restrição, observado o disposto nesta Constituição. $\S 1^{\circ}$ Nenhuma lei conterá dispositivo que possa constituir embaraço à plena liberdade de informação jornalística em qualquer veículo de comunicação social, observado o disposto no art. $5^{\circ}$, IV, V, X, XIII e XIV.

8 Rubens R. R. Casara pondera que o fascínio pelo crime, em um jogo de repulsa e identificação, a fé na penas, apresentadas como remédio para os mais variados problemas sociais (por mais que todas as pesquisas sérias sobre o tema apontem para a ineficácia da "pena" na prevenção de delitos e na ressocialização de criminosos), somados a um certo sadismo (na medida em aplicar uma "pena" é, em apertada síntese, impor um sofrimento) fazem do julgamento penal um objeto privilegiado de entretenimento (CASARA, Rubens. Processo Penal do Espetáculo. Ensaios sobre o Poder Penal, a Dogmática e o Autoritarismo na Sociedade Brasileira. Florianópolis: Empório do Direito, 2015. p. 11). 
Sendo o sensacionalismo o principal combustível da mídia mercantilista ${ }^{9}$, o que nos é apresentado são os "sangue-shows", na feliz expressão de Alexandre Morais da Rosa ${ }^{10}$. Não raro, ouve-se o apresentador, do estúdio, solicitar ao repórter que se encontra na delegacia que "mostre a cara do vagabundo". Deixa de lado que o "vagabundo" (que aqui trataremos por desviante ${ }^{11}$ ) é alguém que, apesar de ter tido sua liberdade cerceada seja pelo estado de flagrância, seja pela presença de algum outro elemento que justifique seu isolamento (alguma espécie de prisão cautelar), não pode ser alijado de seus direitos e garantias fundamentais. Longe da dignidade da pessoa humana, meta-princípio que rege nosso ordenamento jurídico, e fundamento expresso da República Federativa do Brasil (CF, art. $1^{\circ}$, III, e art. $5^{\circ}$, LVII), nas telas da TV todos são presumidamente culpados, e não o contrário.

As mídias de informação, e aqui destacamos primordialmente a televisiva, não se contentam em relatar as falas que circulam no espaço público. Nas palavras de Patrick Charaudeau:

(...) elas contribuem de maneira muito mais ativa para a realização do debate social, dispondo num lugar particular - que é o delas, e que elas dominam - dispositivos que proporcionam o surgimento e o confronto de falas diversas. Esse surgimento e esse confronto não são espontâneos ou ao sabor do debate so-

9 GOMES, Marcus Alan de Melo. Mídia e Sistema penal: as distorções da criminalização nos meios de comunicação. Rio de Janeiro: Revan, 2015. p. 59.

10 ROSA, Alexandre Morais da. A Teoria dos Jogos Aplicada ao Processo Penal. $2^{\mathrm{a}}$ Ed. Lisboa: Rei Livros., 2015. p. 108.

11 Em nossa perspectiva não há como compreender a "criminalidade" sem entender a ação do sistema penal como criadora de um status de "delinquente" ou "criminoso," como decorrente dos efeitos estigmatizantes do próprio sistema. Dentro, pois, de uma perspectiva crítica da construção das identidades crimininosas, e circunscrevendo-nos aos limites de análise dentro do objeto deste artigo, optamos por utilizar aqui o termo "desviante" tomando aquele que supostamente cometeu algum crime e que foi ou preso em flagrante ou mediante o cumprimento de mandado de prisão de natureza cautelar como alguém rotulado em um processo de reação social profundamente vinculado a uma visão política de regulação das relações de poder sobre as classes criminalizadas. Neste sentido ver, essencialmente, entre outros: BARATTA, Alessandro. Criminologia Crítica e Crítica do Direito Penal: introdução à sociologia do direito penal. Rio de Janeiro: Editora Revan: Instituto Carioca de Criminologia, 2002. 
cial que se instaura no espaço público. Trata-se, ao contrário, de uma encenação organizada de tal maneira que os confrontos de falas tornam-se, por si, um acontecimento notável (saliente). O acontecimento é proveniente, aqui, de um dizer que não é um simples recurso para descrever o mundo (a fala do apresentador, do jornalista ou da testemunha), mas uma construção com fins de revelação de uma determinada verdade sobre o mundo. Essa construção é, então, exibida (na imprensa, no rádio, na televisão), e para tanto ela é objeto, como no teatro, de uma mise-en-scène nos dispositivos instalados pela mídia. ${ }^{12}$

No palco deste teatro descrito por Charaudeau, tem-se, pois, um embate entre os interesses da sociedade, supostamente representada "na" e "pela" mídia e seu discurso, e os direitos fundamentais do desviante, cabendo à Autoridade Policial a função de ser o primeiro árbitro estatal desse conflito. Neste contexto, para além da competência para a lavratura do auto de prisão em flagrante e o cumprimento dos mandados nas hipóteses de prisão preventiva e provisória decretadas, cabe à Autoridade Policial, como pontua Guilherme de Souza Nucci, ser "o primeiro juiz do fato" 13 , em nosso sentir, também no que concerne às garantias e direitos fundamentais da pessoa que lhe é apresentada como desviante.

É certo que, muitas vezes, a proximidade da Autoridade Policial com o fato delituoso e com a população configura uma zona de pressão e questionamentos de anseios da sociedade e da mídia. Isso porque o contato imediato do Estado com o crime e seus atores (supostos perpetradores e vítimas) se dá, em geral, numa delegacia de polícia, determinando que a primeira resposta estatal ao crime advenha da Autoridade Policial.

Contudo, mais do que uma postura autômata no cumprimento de requisitos condizentes a lavraturas e cumprimento de mandados e, ao mesmo tempo, responsiva a anseios por punição que se identifi-

12 CHARAUDEAU, Patrick. Discurso das Mídias. São Paulo: Contexto, 2006. p. 188-189.

13 NUCCI, Guilherme S. Manual de Processo Penal e Execução Penal. $12^{\mathrm{a}}$ edição. Rio de Janeiro: Forense, 2015, p. 545. 
cam com a vetusta Lei de Talião ${ }^{14}$, o que se espera de uma autoridade do Estado e, portanto, obviamente, condicionada pela Carta Maior, é o cumprimento de uma missão muito mais elevada. Nesse sentido, o objetivo deste artigo é refletir sobre a atuação da Autoridade Policial neste embate entre os interesses midiáticos e os direitos de privacidade do desviante, sobretudo no concernente ao direito de imagem.

Perguntamos, então: o que, desde uma perspectiva garantista, efetivamente sustenta uma postura de resistência do Delegado ou da Delegada de Polícia às pressões midiáticas no intuito de preservar a imagem do desviante levado à sua autoridade? Mediante pesquisa bibliográfica, a hipótese é a de que a Autoridade Policial, no âmbito de seu poder-dever de zelar pela razoabilidade em um sistema de direitos e garantias fundamentais, não pode render-se à opinião midiática, devendo, como regra, preservar a imagem do desviante detido, admitindo que a mesma seja veiculada somente em circunstâncias peculiares que venham ao encontro de interesse imprescindível da investigação criminal, mas nunca espetacularmente.

\section{GARANTIAS RELACIONADAS À PERSECUÇÃO PENAL NO ESTADO DEMOCRÁTICO DE DIREITO.}

Como já mencionado, somos uma massa de cidadãos e cidadãs aterrorizada pela violência urbana. $\mathrm{O}$ assunto criminalidade tornou-se uma obsessão nacional, crescendo na população o sentimento de absoluta insegurança e impotência, muitas vezes justificado subliminarmente em discursos que isso reputam ao fato de somente ao Estado competir, efetivamente, prestar segurança pública e de ser ele o detentor exclusivo do jus puniendi ${ }^{15}$.

14 Trata-se do princípio da estrita reciprocidade, representado pela máxima do "olho por olho, dente por dente", cujos primeiros indícios foram encontrados no Código de Hamurabi (1780 a.C.). O autor de um delito deveria receber em castigo dano idêntico àquele por ele causado.

15 Poder do Estado de exigir de quem comete um delito a submissão à sanção penal. Decorre diretamente da noção de soberania. 
A persecução penal do Estado Democrático de Direito mais do que um instrumento a serviço do Direito Penal, deve ser mecanismo de efetivação dos direitos fundamentais, servindo de garantia contra a gana punitiva do Estado. O processo penal, nesse contexto, não se pode furtar a seu caráter contramajoritário ${ }^{16}$. Não é outra a lição de Ferrajoli, segundo quem, na tradição liberal democrática, o direito penal e o processo penal são instrumentos da própria democracia se e somente se minimizam a gana punitivista do Estado, configurando um conjunto de limitações a ele impostas. ${ }^{17}$

Os movimentos sociais são pendulares, partindo de um extremo a outro antes de encontrar o seu ponto de equilíbrio. O processo penal brasileiro reflete essa tendência ${ }^{18}$. A CF de 1988 trouxe, em oposição ao regime autoritário que a antecedeu, uma série de garantias relativas à persecução penal, às quais se acrescem outras, decorrentes dos Tratados Internacionais de que o Brasil é signatário e das próprias normas infraconstitucionais. ${ }^{19}$

É bem verdade que o processo penal democrático preconizado na Carta Maior não é, ainda, plenamente vigente em nosso ordenamento jurídico. A democracia brasileira e, consequentemente, a ideia de um processo penal democrático, ainda estão em construção. Tal como adverte Rogério Schietti Machado Cruz, a Constituição Federal tem feições progressistas e preconiza que o processo penal pátrio seja efetivamente democrático, mas é contrariada pela legislação infraconstitucional e sobretudo pela prática judiciária e das investigações criminais, que ainda refletem certo grau de autoritarismo. ${ }^{20}$

16 A concretização de direitos fundamentais demandará, frequentemente, posturas que contrariam a vontade da maioria.

17 FERRAJOLI, Luigi. Justicia penal y democracia. Jueces para La Democracia, n. 4, Madrid, set./1988, p. 3 (tradução livre).

18 FERNANDES, Antônio Scarance. Processo Penal Constitucional. $7^{\mathrm{a}}$ Ed. São Paulo: Revista dos Tribunais, 2012. p. 23.

19 Vale pontuar que desde a EC n. 45/2004, os Tratados Internacionais de Direitos Humanos, desde que aprovados, em cada Casa do Congresso Nacional, segundo o mesmo rito destinado às Emendas Constitucionais, a elas equivalerão, passando, portanto, a ter caráter de norma constitucional e não mais supralegal como entendia o Supremo Tribunal Federal (CF, art. $5^{\circ}$, p. $3^{\circ}$; STF, RE 466.343-SP e HC 87.585-TO).

20 CRUZ, Rogério Schietti Machado. Rumo a um processo penal democrático. In: MACHADO, Bruno Amaral (Coord.). Justiça Criminal e Democracia. 
Não obstante, a busca pela institucionalização do modelo democrático preconizado pela norma constitucional, um modelo de matriz indubitavelmente garantista ${ }^{21}$, deve ser incansável.

Desde 1988 o processo penal brasileiro tem passado por sucessivas reformas que o modernizaram, com vistas a afastar a persecução penal do modelo de tradição autoritária que predominou ao longo de nossa história, e a aproximá-la dos ideais democráticos e garantistas da ordem constitucional. Um quadro de transformações que busca refletir o fato de o Estado Democrático de Direito (e, consequentemente, o processo penal democrático) ter fundamento no metaprincípio da dignidade da pessoa humana $^{22}$, do qual decorre a grande maioria dos direitos fundamentais.

Como ensina Jorge Miranda, a dignidade da pessoa humana significa tratar a pessoa como fundamento e fim da sociedade e do Estado $^{23}$, de modo que o metaprincípio abrange não só a dignidade de cada indivíduo, mas também a dignidade de todos. Trata-se, segundo o autor, de um “(...) valor absoluto. Pode haver ponderação da dignidade de uma pessoa com a dignidade de outra pessoa, não com qualquer outro princípio ou interesse" ${ }^{24}$.

Brasília: Fundação Escola Superior do Ministério Público do Distrito Federal e Territórios, 2013. p. 28 (sem destaques no original).

21 Não se pode, aqui, deixar de consignar e lamentar a recente decisão prolatada pelo Supremo Tribunal Federal no HC 126.292, segundo a qual, a despeito do texto expresso da Constituição Federal (CF, art. 5, LVII - ninguém será considerado culpado até o trânsito em julgado de sentença penal condenatória); é admissível o cumprimento provisório de pena confirmada em Segunda Instância. Partilhamos do inconformismo expressado por Cezar Roberto Bitencourt e Vania Barbosa Adorno Bitencourt em artigo publicado, no sentido de que o entendimento da Corte viola o princípio da presunção de inocência (BITENCOURT, Cezar Roberto; BITENCOURT, Vania Barbosa Adorno. Em dia de terror, Supremo rasga a Constituição no julgamento de um HC. Disponível em: <http://www.conjur.com.br/2016-fev-18/cezar-bittencourt-dia-terror-stf-rasga-constituicao $>$. Acesso em: 02 mai. 2017).

22 Lembrando que a norma constitucional, segundo Canotilho, deve ser interpretada no sentido que lhe conferir maior eficácia: CANOTILHO, José Joaquim Gomes. Direito Constitucional. $7^{\text {a }}$ Ed. Coimbra: Almedina, 2003. p. 1224. O ser humano é sujeito de direito; não pode ser tratado como mero objeto.

MIRANDA, Jorge. A Dignidade da Pessoa Humana e a Unidade Valorativa do Sistema de Direitos Fundamentais. In: MIRANDA, Jorge; SILVA, Marco A. (coord.). Tratado Luso-Brasileiro da Dignidade Humana. São Paulo: Quartier Latin, 2008. p. 170 (sem destaque no original). 
Partindo dessa ideia, o autor estabelece algumas decorrências do metaprincípio, dentre elas a constatação de que a dignidade de uma pessoa deverá ser protegida a despeito de seus comportamentos sociais, ainda que ilícitos e sancionados pelo direito penal. Pondera que como nenhuma pena implica perda de direitos civis, os condenados em geral continuam titulares de seus direitos e garantias fundamentais. ${ }^{25}$

Veda-se, pois, a submissão de qualquer pessoa, ainda que presa, a uma "condição de humilhação" 26 , afinal, "ninguém será submetido a tortura e nem a tratamento desumano ou degradante" (CF, art. $5^{\circ}$, III). Dados estes pressupostos, vale que pensemos sobre o direito individual à imagem e à presunção de inocência.

O direito à imagem é um corolário inquestionável da dignidade humana. E o Texto de 1988 o previu expressamente em seu art. $5^{\circ}$, X: "são invioláveis a intimidade, a vida privada, a honra e a imagem das pessoas, assegurado o direito a indenização pelo dano material ou moral decorrente de sua violação" 27 . Trata-se de um dos direitos da personalidade, que, como pontuado por Ingo Wolfgang Sarlet, dizem respeito à integridade e identidade moral da pessoa ${ }^{28}$.

25 Ibidem, p. 174.

26 Expressão utilizada pela Ministra Carmen Lúcia na discussão do Habeas Corpus n. 89.429/RO, em que o paciente pretendia, entre outros, o reconhecimento do direito de não ser filmado algemado. A ordem foi concedida para vedar a utilização das algemas.

$27 \mathrm{O}$ inciso $\mathrm{X}$ do art. $5^{\circ}$ da CF consagra o Direito à Imagem, mas ele também é mencionado em outros incisos: V, que assegura indenização por dano moral, material ou à imagem; e, XXVIII, a, que prevê proteção contra a reprodução da imagem e da voz humana.

28 Os direitos à honra, à imagem, juntamente com o direito à privacidade, o direito à palavra, o direito ao nome, o direito ao conhecimento da paternidade (origem), entre outros, ocupam lugar de destaque na constelação dos direitos pessoais (ou de personalidade), mas, a despeito dos pontos de contato com outros direitos fundamentais, distinguem-se pelo fato de dizerem respeito mais propriamente à integridade e identidade moral da pessoa, não tendo, portanto, âmbito de proteção coincidente com os direitos à privacidade e à intimidade. Além disso, convém lembrar - pois não se trata de aspecto irrelevante mesmo para uma perspectiva constitucional - que os direitos à honra e à imagem foram previstos no capítulo do Código Civil relativo aos direitos da personalidade (art. 20, caput). (SARLET, Ingo Wolfgang; MARINONI, Luiz Guilherme; MITIERO, Daniel. Curso de Direito Constitucional. ${ }^{\mathrm{a}}$ Ed. São Paulo: Revista dos Tribunais, 2013, p. 434). 
O direito à imagem abrange não só os atributos físicos de uma pessoa (imagem-retrato), mas também o direito de definir e determinar a auto-exposição, vedando, como regra, que a pessoa seja fotografada ou retratada sem seu devido consentimento ${ }^{29}$. Evidentemente, nada impede a cessão do uso da imagem ${ }^{30}$, mas sua utilização indevida enseja direito de indenização pelo dano moral ou material sofrido.

É de suma relevância ponderar, entretanto, que danos à imagem são de tal dimensão que se poderiam dizer muito próximos da irreparabilidade, especialmente em tempos de rede mundial de computadores. Uma vez lançada na internet, a informação dificilmente se perderá, nem mesmo em se invocando o direito ao esquecimento.

Em sendo, assim, o direito à imagem uma das decorrências do primado da dignidade humana ${ }^{31}$, forçoso é concluir que ele não se aparta nem mesmo dos desviantes detidos. A rigor, a exposição da imagem das pessoas nessa condição demandaria sua expressa aquiescência, o que, evidentemente, não é o padrão da prática.

A praxe policial é admitir que a imprensa divulgue amplamente a imagem do desviante logo após a captura, ainda na delegacia de polícia, quase sempre ainda algemada, como se se tratasse de "caça", "tro-

29 SARLET, Ingo Wolfgang; MARINONI, Luiz Guilherme; MITIERO, Daniel. Curso de Direito Constitucional. $2^{\mathrm{a}}$ Ed. São Paulo: Revista dos Tribunais, 2013. p. 439-440.

30 Os direitos fundamentais são ditos inalienáveis, mas limitações voluntárias de direitos específicos são admissíveis desde que razoáveis com a finalidade que pretendem atingir. Neste sentido ver MENDES, Gilmar F.; BRANCO, Paulo Gustavo Gonet. Curso de Direito Constitucional. 6 ${ }^{\mathrm{a}}$ Ed. São Paulo: Saraiva, 2011. p. 164-166, em especial nota de rodapé n. 43.

31 Vale retomar, aqui, os ensinamentos de Jorge Miranda, para quem a dignidade da pessoa humana é um valor absoluto que não pode ser ponderado senão com a dignidade de outra pessoa, jamais com qualquer outro princípio ou interesse. Decorre daí, segundo o autor, que a dignidade da pessoa humana é um prius perante a vontade popular, por sua vez subordinada à dignidade da pessoa humana. E uma ordem jurídica fundada na dignidade humana não pode se apartar da ideia kantiana de que o homem jamais pode ser instrumento ou meio a serviço de outro homem. Neste sentido em: MIRANDA, Jorge. A Dignidade da Pessoa Humana e a Unidade Valorativa do Sistema de Direitos Fundamentais. In: MIRANDA, Jorge; SILVA, Marco A. (coord.). Tratado Luso-Brasileiro da Dignidade Humana. São Paulo: Quartier Latin, 2008. p. 170. 
féu" ${ }^{32}$, a ser exposto à curiosidade comunitária. Sob uma perspectiva garantista, essa postura não parece ser constitucional, pelo que deveria ser coibida pela Autoridade Policial. Vale ponderar, neste ponto que o desviante detido nas condições aqui cogitadas (flagrante ou cumprimento de mandado de prisão cautelar) em geral não foi nem sequer indiciado, militando em seu favor, portanto, a presunção constitucional de inocência.

A Carta Magna estabeleceu, no art. 5º LVII, “que ninguém será considerado culpado até o trânsito em julgado de sentença penal condenatória”, internalizando expressamente, no ordenamento jurídico pátrio, a garantia da não culpabilidade, postulado universal de Direito previsto na Declaração dos Direitos Humanos de 1948. Neste aspecto, Aury Lopes Júnior e Gustavo Henrique Badaró, em parecer, ponderaram que, politicamente, a presunção de inocência é um consectário necessário do Estado de Direito e corolário do sistema acusatório. ${ }^{33}$

Vale reiterar que a presunção de inocência apenas foi positivada, entre nós, com a CF de 1988, de forma que, mesmo passados quase trinta anos de nova ordem constitucional, seu preceito normativo e suas decorrências ainda não foram plenamente incorporados ao agir dos personagens da persecução penal. Além de uma garantia política, a presunção de inocência deve ser encarada como uma regra de tratamento do cidadão e da cidadã. Ela implica, sob este viés, a ilegitimidade de se impor à pessoa investigada/denunciada consequências jurídicas decorrentes do inquérito/processo antes de a condenação ter se tornado definitiva.

Em síntese, à vista da necessidade de prevalência do direito de imagem e do respeito à presunção de inocência, é de afirmar-se que qualquer processo penal que se pretenda democrático traz em seu bojo normas (regras e princípios) que protegem o indivíduo face

32 O Ministro Sepúlveda Pertence, nas deliberações do HC n. 89.429/RO, do STF, defendeu arduamente a tese de que não se pode transformar a pessoa em troféu da diligência policial.

33 Presunção de inocência: do conceito de trânsito em julgado da sentença penal condenatória, p. 7-8. Disponível em: <http://emporiododireito.com.br/wpcontent/uploads/2016/06/Parecer_Presuncao_de_Inocencia_Do_concei. pdf>. Acesso em: 30 jan. 2017. 
ao Estado. E é o quanto dessas normas é respeitado que determina se a persecução penal se dá de fato em ambiente democrático. Uma das marcas do Estado de Direito, portanto, é o controle do poder. Ao mesmo tempo em que cria a lei, o Estado Democrático se submete a ela, evitando arbítrios e autoritarismos. E, no âmbito da persecução penal, esse controle implica maximização da liberdade e minimização do próprio direito de punir.

Contudo, por vezes parece incompreensível, pelo que se percebe no discurso midiático, o fato de que a persecução penal encontra limitações, na medida em que apenas pode ser exercida segundo as regras do jogo.

\section{A LIBERDADE DE INFORMAÇÃO JORNALÍSTICA E O DISCURSO MIDIÁTICO}

Liberdade e igualdade são elementos essenciais da dignidade humana, pois, na lição de Paulo Gustavo Gonet Branco, o ser humano se forma no contato com o seu semelhante. ${ }^{34}$

Garantida, por sua vez, a liberdade de expressão no art. $5^{\circ}$, IV, da CF, dela decorrem, logicamente, outras liberdades, como a de informação jornalística que, nos termos do art. 220, não sofrerá restrição ou censura. A vedação à censura denota que a liberdade de informação é um direito de índole defensiva, no sentido de que não cabe ao Estado tutelar as opiniões que serão expressadas pela mídia e nem filtrar as notícias que devem ou não ser veiculadas.

Não obstante, assim como qualquer outro direito ou garantia fundamental, também quanto à liberdade de informação não se cogita de direito absoluto, visto que deve ser ponderado diante da sua eventual colisão com outros direitos. Admite-se, portanto, que seja limitada a liberdade de informação, atendendo ao critério de proporcionalidade ${ }^{35}$.

34 BRANCO, Paulo Gustavo Gonet; MENDES, Gilmar F. Curso de Direito Constitucional. 6a Ed. São Paulo: Saraiva, 2011. p. 296-297.

35 A própria CF traz algumas limitações. O respeito à dignidade pessoal é uma delas, prevista no art. 221. Vale salientar que restrições a direitos fundamentais são legítimas se afinadas às exigências da proporcionalidade e à preser- 
Importa salientar, mais uma vez, que a liberdade de informação tem função relevante numa ordem democrática e plural, podendo-se mesmo falar, como faz Ingo Wolfgang Sarlet, em valor central do Estado Democrático de Direito ${ }^{36}$.

Sem embargo, a mídia detém, sem dúvidas, poder no nosso tempo. Vivemos na "Idade Mídia" ${ }^{37}$. Ela constrói socialmente a realidade segundo seus interesses. Patrick Champagne sustenta mesmo que "a difusão dos novos meios modernos de comunicação [...] implicaram um deslocamento progressivo do centro de gravidade do espaço político, que passou das assembleias parlamentares para a mídia"38. Como ponderam Aline Diel e Maiquel Wermuth, "ela não dita, necessariamente, às pessoas o que pensar, mas decide no que elas irão pensar" ${ }^{39}$.

Infelizmente, pouco consciente da repercussão de seu poder, ou despreocupada com isso, parte da mídia tem assumido uma postura temerária no tocante à exposição da criminalidade. O crime se transformou num de seus produtos que, definido como um fetiche ${ }^{40}$, tanto oculta o processo de produção ligado aos objetivos da afirmação do medo e da cultura punitivista como, em sua relação com o público, confere à

vação do respectivo núcleo essencial do direito afetado. Nesse sentiodo: SARLET, Ingo Wolfgang. Direitos fundamentais viveram série de retrocessos no plano fático e jurídico. Disponível em: <http://www.conjur.com.br/ 2016-dez-30/retrospectiva-2016-direitos-humanos-viveram-serie-retrocessos>. Acesso em: 12 jan. 2017.

36 SARLET, Ingo Wolfgang; MARINONI, Luiz Guilherme; MITIERO, Daniel. Curso de Direito Constitucional. 2a Ed. São Paulo: Revista dos Tribunais, 2013. p. 458.

37 Expressão cunhada pelo Ministro Carlos Britto, no julgamento do HC 89.429/ RO, Ele ponderou, na ocasião, que: não se pode espetaculizar o ofício público, sobretudo nessa quadra histórica que bem poderíamos chamar de "idade mídia", parafraseando a "idade média".

CHAMPAGNE, Patrick. Formar a opinião. O novo jogo político. Petrópolis. Ed Vozes, 1998. Tradução de Guilherme João de Freitas Teixeira. p. 139.

39 DIEL, Aline Ferreira da Silva; WERMUTH, Maiquel Anggelo Dezordi. Desvelando o arauto: mídia, crime e direitos humanos em tempos difíceis. In: SOUZA Bernardo de Azevedo e; SILVEIRA, Felipe Lazzari da (orgs.). Democracia e $(m)$ Sistema Penal. Porto Alegre: Canal Ciências Criminais, 2017. p. 38.

40 MORETZSOHN, Sylvia. Jornalismo em "tempo real": o fetiche da velocidade. Rio de Janeiro: Revan, 2002. p. 120-121. 
notícia aparente valor de uso para legitimar toda e quaisquer formas de apartamento social dos rotulados como "criminosos".

Historicamente, o direito penal surgiu como negação da vingança privada. O Estado assumiu para si a tarefa de manter a ordem social ${ }^{41}$ e de punir quem a subvertesse. As promessas de sistemas preventivos e punitivos, entretanto, fracassaram e ensejaram o estado generalizado de pânico moral do qual a mídia se apodera, canalizando o desejo humano de vingança. Ela não apenas expõe a criminalidade violenta ${ }^{42}$, mas também clama por soluções drásticas: penas mais longas, de preferência perpétuas, encarceramento imediato independentemente de comprovação da culpabilidade, leis mais severas, etc. A prudência não tem espaço na "criminologia midiática”, para usar uma expressão de Zaffaroni.

Evidente que esse discurso midiático não é apanágio da atualidade. Ele sempre existiu, mas variou muito no tempo, sobretudo em razão da tecnologia de comunicação de cada época. Atualmente, conta com a força da televisão e do uso das imagens que ela viabiliza. Fundamenta-se numa ideia neopunitivista que decorre de uma ânsia geral por respostas urgentes. ${ }^{43}$ Acredita-se que basta aumentar as penas e o arbítrio policial para que haja redução de delitos.

Um problema desse discurso ${ }^{44}$ é que ele se volta contra determinados grupos humanos já naturalmente marginalizados, apresentan-

41 Como salientado por George L. Kelling e James Q. Wilson no clássico artigo escrito para a revista the Atlantic de março de 1982 (Broken Windows. The Police and neighborhood safety. Disponível em: <http://www.theatlantic.com/magazine/archive/1982/03/broken-windows/304465/>. Acesso em: 4 mai. 2017), a percepção de insegurança é diretamente proporcional à desordem social. Não por outro motivo, a função original das polícias era a manutenção da ordem pública. Daí que nos governos ditatoriais que controlam a mídia, a população não se apercebe dos índices de criminalidade, pois os ditadores não podem tolerar a menor denuncia midiática de desordem, pois negariam sua falsa imagem de provedores de segurança (ZAFFARONI, Eugênio Raúl. A palavra dos mortos. Conferências de Criminologia Cautelar. São Paulo: Saraiva, 2012. p. 327).

42 Quase sempre se trata de homicídios, roubos/latrocínios ou crimes sexuais.

43 ZAFFARONI, Eugênio Raúl. A palavra dos mortos. Conferências de Criminologia Cautelar. São Paulo: Saraiva, 2012. p. 303.

44 Além, é claro, de sua questionável compatibilidade com o sistema de garantias fundamentais preconizado pela CF. 
do-os como culpados de toda a criminalidade. São uma massa estereotipada de criminosos, "que configuram um 'eles' separado do resto da sociedade, por ser um conjunto de 'diferentes e maus"” 45 .

Esse "eles", potencialmente desviante e ontologicamente ameaçador, geralmente identifica-se com o "outro", "historicamente oprimido e explorado, indivíduo despojado de seus direitos, 'coisificado', vítima da exclusão". ${ }^{46}$ Um "outro" tornado personagem principal para a difusão da cultura punitiva que prepondera em nosso país desde uma visão maniqueísta e simplista que ignora o fato de que estamos todos submetidos à mesma ordem, "todos imersos numa intrincada rede em que os elos se alternam". ${ }^{47}$

Produto e ao mesmo tempo combustível desta lógica punitivista será, então, a cultura do medo ${ }^{48}$. Um sentimento generalizado de vitimização, reproduzido a partir do maniqueísmo social, segundo o qual, "os bons se transformam em vítimas indefesas dos maus, incluído, nesta última categoria os supostos responsáveis pela segurança de todos. Daí as expressões: impunidade, ineficácia das normas e do judiciário.” ${ }^{49}$

A espetaculização do inquérito penal pode levar à formação de um juízo coletivo de culpabilidade daquele suposto desviante, que nem sequer foi ainda indiciado, podendo esse juízo ser deletério até mesmo para a atuação jurisdicional. Em verdade, nesse contexto, parafraseando

45 ZAFFARONI, Eugênio Raúl. A palavra dos mortos. Conferências de Criminologia Cautelar. São Paulo: Saraiva, 2012. p. 307

46 BOLDT, Raphael. Criminologia Midiática: do discurso punitivo à corrosão simbólica do garantismo. Curitiba: Juruá, 2013. p. 30.

47 OLIVEIRA, Luciano. Manual de Sociologia Jurídica. Petrópolis: Vozes. 2015. p. 64-65.

48 Utilizamos aqui o medo nos termos trabalhados por Débora Pastana (IBCCRIM, 2003, p. 92): "Entendemos o medo, neste estudo, como uma forma de exteriorização cultural, principalmente se levarmos em conta as transformações que ele desencadeia. Como vimos no capítulo anterior, há uma mudança no comportamento do indivíduo em casa e na rua, um cuidado maior com os bens (consumo de apólices de seguro, por exemplo), a produção e o consumo dos mais variados produtos de segurança privada (alarmes, vidro blindado e aulas de defesa pessoal, por exemplo), uma desconfiança generalizada entre os indivíduos".

49 PASTANA, Débora Regina. Cultura do medo: reflexões sobre violência criminal, controle social e cidadania no Brasil. São Paulo: IBCCRIM, 2003, p. 92. 
Nilo Batista, não se trata de influenciar um tribunal, senão de realizar diretamente o próprio julgamento. ${ }^{50}$

Esse discurso midiático fundamentaria tranquilamente as teorias que legitimam a exasperação da pena. Ocorre que esses mecanismos, em especial o direito penal do inimigo ${ }^{51}$, não são compatíveis com o Estado Democrático de Direito, que não admite a ideia de duas gamas de direitos: os do cidadão e o do não-cidadão.

Ademais, o crime não pode ser encarado como um fenômeno meramente individual. Muito pelo contrário. Não é possível compreender o comportamento humano fora do contexto social, pois ele não se acha condicionado somente às características que herdamos de nossos pais. Ele é também fruto das condições ambientais que originam experiências de vida e dos fenômenos culturais a que a pessoa é submetida ${ }^{52}$.

É ainda pertinente pontuar que a sociedade de consumo, com seus apelos individualistas ensejadores de graves desigualdades sociais e o consequente descrédito do Estado de bem-estar, é fonte da criminalidade, forçando o recrudescimento do Estado penal ${ }^{53}$ e a manutenção

50 BATISTA, Nilo. Mídia e sistema penal no capitalismo tardio. Disponível em: <http://www.bocc.ubi.pt/pag/batista-nilo-midia-sistema-penal.pdf >. Acesso em: 03 mai. 2017. p.16.

51 Em linhas gerais, parte-se da concepção de Pacto Social e preconiza que há duas classes de pessoas num Estado: os cidadãos e os inimigos. Os cidadãos são aquelas pessoas que aderiram ao pacto social. Por tal motivo, são merecedoras da proteção do Estado. Os inimigos são de tal forma desviantes do pacto, que não podem ser considerados inseridos no Estado e, portanto, não são merecedores de suas proteções e garantias. A ideia é a de que quem não se submete ao pacto não pode dele se beneficiar. Os direitos e as garantias constitucionais a eles não se aplicam. Neste sentido ver, essencialmente, entre outros: ZAFFARONI, Raúl E. $O$ inimigo no direito penal. Rio de Janeiro: Editora Revan: Instituto Carioca de Criminologia, 2007. O movimento de lei e ordem partilha dessa dicotomia, dividindo a sociedade entre homens bons e maus e defendendo que a violência destes só pode ser controlada por leis severas que imponham a segregação dos criminosos mediante penas privativas de liberdade extremamente intensas, quando não perpétuas ou de morte.

52 FARIAS, Paulo José Leite. Ordem urbanística e a prevenção da criminalidade. Revista de Informação Legislativa. Brasília, ano 42, n. 168 out/dez/2005, p. 173.

53 Nele a função da pena é excluir e neutralizar o desviante. Não se cogita de ressocialização ou de reinserção do desviante na comunidade. 
da estrutura social vigente. ${ }^{54}$ Zaffaroni também visualiza esse mote do discurso midiático, afirmando mesmo que a criminologia midiática visa ao desmantelamento do Estado do bem-estar, na medida em que apenas ele tem aptidão real para a incorporação de novas camadas sociais a uma cidadania real..$^{55}$

O discurso midiático embasa-se fortemente em estereótipos lançados sobre determinados grupos sociais. Selecionam-se imagens daqueles que delinquem e logo em seguida são veiculadas imagens de seus semelhantes, que embora jamais tenham delinquido, se parecem com os delinquentes e assim podem vir a delinquir. Tal como ensinam Guareschi e Biz, conhecer a realidade midiática passa por reconhecer que a mídia é um personagem que é "o único, praticamente, que fala, estabelece com os interlocutores uma comunicação vertical, de cima para baixo; não faz perguntas, apenas dá respostas." ${ }^{\circ 6}$

Essa lógica trazida para o campo processual penal, especialmente investigativo, em tudo contrária ao princípio da presunção de inocência, é deletéria também à paridade de armas que deve viger na persecução penal do Estado Democrático de Direito, decorrência do devido processo legal e do princípio da igualdade. O processo penal democrático deve ser o processo penal do equilíbrio. E a exposição extremada do desviante detido na mídia tem o condão de desequilibrar a balança, especialmente nos casos dos crimes dolosos contra a vida, vez que gera na população uma presunção de culpa dissociada de todo o sistema.

Por outro lado, a mídia insiste fortemente na negação de direitos aos desviantes, como se não fossem destinatários da proteção constitucional à dignidade da pessoa humana e como se tal viés, de matriz garantista, inviabilizasse as punições penais. Na verdade, não existe incompatibilidade entre a eficiência da persecução penal e o garantismo, vetores que não se opõem, antes se complementam, pois não se

54 BELLI, Benoni. Tolerância Zero e Democracia no Brasil: visões da segurança pública na década de 90. São Paulo: Perspectiva, 2004. p. xvi.

55 ZAFFARONI, Eugênio Raúl. A palavra dos mortos. Conferências de Criminologia Cautelar. São Paulo: Saraiva, 2012. p. 331.

56 GUARESCHI, Pedrinho A. BIZ, Osvaldo. Mídia \& democracia. Porto Alegre: PG/OB, 2005. p. 66. 
concebe um processo eficiente sem garantismo" ${ }^{57}$. Qualquer intervenção legítima que se faça aos núcleos dos direitos deve ser embasada nos parâmetros do Estado Democrático de Direito ${ }^{58}$, e à Autoridade Policial compete zelar pelos direitos e garantias fundamentais de todos os atores do crime, especialmente da vítima e do desviante.

\section{O PAPEL DAAUTORIDADE POLICIAL}

O Delegado ou a Delegada de Polícia são a autoridade pública responsável pelas funções de polícia investigativa e de polícia judiciária. São a autoridade policial por excelência ${ }^{59}$. Como ensina Nereu José Giacomolli:

O inquérito policial há de ser conduzido pela autoridade do inquérito, ou seja, pelo Delegado de Polícia e não por outros servidores. O conhecimento da totalidade da investigação, suas diversas perspectivas, é de ser outorgado ao condutor do inquérito $(. . .)^{60}$

A polícia é um braço do Estado Democrático de Direito ${ }^{61}$. Tratando do Poder Judiciário, mas em lição que pode perfeitamente

57 FERNANDES, Antonio Scarance. Processo Penal Constitucional. $7^{\mathrm{a}}$ Ed. São Paulo: Revista dos Tribunais, 2012. p. 23 (sem destaque no original).

58 Direitos fundamentais viveram série de retrocessos no plano fático e jurídico. Retrospectiva 2016. Disponível em: <http://www.conjur.com.br/ 2016-dez-30/retrospectiva-2016-direitos-humanos-viveram-serie-retrocessos>. Acesso em: 12 jan. 2017.

59 Os demais servidores do sistema (os policiais em sentido geral) são agentes da autoridade.

60 GIACOMOLLI, Nereu J. Qualidade do Inquérito Policial. In: AMBOS, Kai; MALARINO, Ezequiel; VASCONCELOS, Eneas Romero. (orgs). Polícia e Investigação no Brasil. Brasília: Gazeta Jurídica, 2016. p. 156.

61 Não se pode, entretanto, esquecer que, como já mencionado antes, os movimentos sociais partem de um extremo a outro antes de encontrarem um ponto de equilíbrio. Nessa ordem de ideias, em oposição ao regime autoritário que a antecedeu, a CF de 1988, embora tenha atribuído à polícia a função investigar, restringiu-lhe a força, sobretudo exigindo autorização judicial para diversas diligências policiais antes realizadas meramente pela ordem do Delegado de Polícia. 
ser transposta para a polícia, Zaffaroni esclarece que independentemente da eleição ou não dos seus integrantes, uma instituição será tida como democrática se atender ao sistema democrático, no sentido de ser necessária a sua efetivação e continuidade. ${ }^{62}$ Assim deve ser vista a polícia investigativa.

É ela o primeiro órgão do Estado que lhe efetiva a política criminal. É a ela que os cidadãos recorrem em primeiro lugar para a tutela de seus direitos e liberdades. A Polícia, como pontua Manuel Monteiro Guedes Valente, é "o promotor visível da concretização dos vetores da política criminal - legitimidade e eficácia - e dos seus princípios - legalidade, culpabilidade, humanidade e ressocialização do delinquente" ${ }^{63}$. Deve ter identidade com a defesa dos direitos humanos.

Um dos maiores desafios da polícia no Estado Democrático de Direito é encontrar o equilíbrio entre a efetiva tutela dos bens jurídicos protegidos e a proteção do desviante face ao Estado (garantismo vs. securitarismo). Vale lembrar que uma das faces do princípio da proporcionalidade é a vedação da proteção insuficiente, que torna ilegítima a omissão estatal no tocante a seu dever de proteção da sociedade, tanto quanto são ilegítimos os excessos cometidos contra o desviante. Rogério Schietti Machado Cruz esclarece, nesse sentido:

Daí a importância de ter, não apenas o juiz, mas também o responsável pela persecução penal, uma preocupação permanente de buscar o equilíbrio entre, de um lado, o dever de manter a ordem e a segurança sociais, de que resulta o interesse punitivo do Estado (e, antes, da sociedade) e, de outro lado, o interesse de proteção da liberdade do indivíduo (que também é de interesse de todos). ${ }^{64}$

${ }^{62}$ ZAFFARONI, Eugênio Raúl. Poder Judiciário. Crise, acertos e desacertos. Trad. Juarez Tavarez. São Paulo: RT. 1995. Apud CRUZ, Rogério Schietti Machado. Rumo a um processo penal democrático. In: MACHADO, Bruno Amaral (Coord.). Justiça Criminal e Democracia. Brasília: Fundação Escola Superior do Ministério Público do Distrito Federal e Territórios, 2013. p. 49. VALENTE, Manuel Monteiro Guedes. A Polícia do Estado Democrático e de Direito. Florianópolis: Empório do Direito, 2015. p. 18.

${ }^{64}$ CRUZ, Rogério Schietti Machado. Rumo a um processo penal democrático. In: MACHADO, Bruno Amaral (Coord.). Justiça Criminal e Democracia. 
O Delegado ou a Delegada de Polícia personificam essa instituição, cabendo-lhes apreciar as infrações penais que lhes são apresentadas por seus agentes, avaliando os fatos com base em seus conhecimentos jurídicos e em sua experiência profissional. Uma atuação que deve ser pautada não apenas por critérios de objetividade e imparcialidade, em absoluto compromisso com a verdade ${ }^{65}$, mas também pelos princípios fundamentais do sistema. O Delegado ou a Delegada de Polícia devem aplicar as leis de forma proporcional e razoável, atuando, pois, nas palavras do Ministro Celso De Mello, como "o primeiro garantidor da legalidade e da Justiça" ${ }^{66}$, em constante respeito ao metaprincípio da dignidade humana. Nunca é demais repetir que as garantias constitucionais e internacionais de direitos humanos se aplicam desde a fase de investigação criminal $^{67}$, e, como titular do inquérito, cabe ao Delegado ou à Delegada zelar pela sua efetivação.

Brasília: Fundação Escola Superior do Ministério Público do Distrito Federal e Territórios, 2013. p. 50.

65 Num Estado Democrático de Direito, interessa à comunidade jurídica não só a punição de todos os culpados, mas também que nenhum inocente seja punido. Como sabemos imparcialidade não se confunde com neutralidade, sendo este mais um mito da modernidade. Neste sentido, no processo penal, o juiz/a, ainda que seja sujeito da relação processual, "sua atuação deverá despojar-se de influências de caráter subjetivo que o impeçam de resolver com exatidão e justiça” (LOPES Jr., Aury. GLOECKNER, Ricardo Jacobsen. Investigação Preliminar no Processo Penal. São Paulo: Saraiva, 2014, p. 136). Por outro lado, mesmo a imparcialidade, no que toca à ação do Ministério Público, é também um mito. (CASARA, Rubens. Mitologia Processual Penal. São Paulo: Saraiva, 2015.). Contudo, no que concerne à atribuição da Autoridade Policial é de observar-se que a mesma não pode afastar-se da imparcialidade, posto que não pode direcionar-se a buscar elementos de convicção para a condenação do desviante, mas sim para a elucidação das circunstâncias, da autoria e da materialidade da infração penal. STF, HC 84.548, Rel Min. Marco Aurélio, DJ 21/6/2012.

67 As garantias de Direitos Humanos devem ser deferidas aos imputados, aí compreendidos os investigados e os réus. Esse termo, "imputado", é usado textualmente no Código de Processo Penal Argentino. Entre nós, a jurisprudência do STJ já teve oportunidade de determinar o trancamento de inquérito policial que tramitou sem consideração ao direito fundamental ao sigilo das comunicações, demonstrando que se admite a incidência dos direitos decorrentes da dignidade humana desde a fase investigativa (HC 117.437/AP, Rel. Ministro Jorge Mussi, quinta turma, julgado em 04/10/2011, DJe 20/10/2011). 
A Federação Nacional dos Delegados de Polícia elaborou um Plano Nacional de Defesa Social e Aperfeiçoamento da Democracia no qual foi previsto o chamado Pacto pela Moralidade, Legalidade e Cidadania. Dele consta claramente que uma das funções do Delegado ou da Delegada de Polícia é zelar pelo respeito dos direitos fundamentais do preso, havendo menção expressa à necessidade de enfrentamento das "arbitrariedades na vigilância e guarda de indivíduos submetidos à autoridade do agente público" ${ }^{68}$.

Segundo Leonardo Marcondes Machado, o castigo decorrente da persecução penal estabelece-se muito antes da condenação, desde que recai alguma suspeita sobre o desviante ${ }^{69}$. Não é por outro motivo que nossas Cortes Superiores vislumbram a possibilidade de constrangimento ilegal desde a instauração do inquérito penal, admitindo o seu trancamento quando evidentemente ausente a condição da justa causa ${ }^{70}$.

68 Item A.3. da Cartilha Prática de Orientações aos Delegados de Polícia no Cumprimento do Pacto pela Legalidade e Moralidade - FENDEPOL. Disponível em: <http://fendepol.com/documentos/cartilha-pacto-moralidade.pdf $>$. Acesso em: 3 mai. 2017.

${ }^{69}$ MACHADO, Leonardo Marcondes. Investigação Preliminar: por uma política de redução de dor. In: KHALED JR. Salah H. (coord.). Sistema Penal e Poder Punitivo. Estudos em homenagem ao Prof. Aury Lopes Jr. Florianópolis: Empório do Direito, 2015. p. 334.

70 No STJ - RHC 72.074/MG, Rel. Ministro Ribeiro Dantas, Quinta Turma, julgado em 06/10/2016, DJe 19/10/2016; HC 353.417/BA, Rel. Ministro Antonio Saldanha Palheiro, Sexta Turma, julgado em 25/10/2016, DJe 17/11/2016; RHC 75.048/BA, Rel. Ministro Reynaldo Soares Da Fonseca, Quinta Turma, julgado em 25/10/2016, DJe 07/11/2016, de cuja ementa se colhe: o trancamento de ação penal ou de inquérito policial, em sede de habeas corpus ou recurso ordinário, constitui medida excepcional, somente admitida quando restar demonstrado, sem a necessidade de exame do conjunto fático-probatório, a atipicidade da conduta, a ocorrência de causa extintiva da punibilidade ou a ausência de indícios suficientes da autoria ou prova da materialidade (sem destaques no original). No STF - RHC 117988, Relator(a): Min. Gilmar Mendes, Relator(a) p/ Acórdão: Min. Celso De Mello, Segunda Turma, julgado em 16/12/2014, processo eletrônico dje-037 divulg 25-02-2015 public 26-02-2015; pet 4979, relator(a): min. Roberto Barroso, primeira turma, julgado em 23/06/2015, acórdão eletrônico dje-184 divulg 16-09-2015 public 17-09-2015, em que se determinou o trancamento da notitia criminis, antes mesmo, portanto, da instauração de procedimento investigativo ou ação penal. 
É importante ter em mente que a advertência feita por Rubens Casara, no sentido de que "a relação entre "prisão" e "liberdade" revela uma manifestação de poder (e que a contenção do poder é o núcleo da dimensão política do Processo Penal)" 71 , de modo que o Estado, ao violar a lei e afrontar direitos fundamentais, perde sua "superioridade ética, [... e] acaba por se igualar ao criminoso"72, o que jamais pode ser admitido num Estado que se pretende democrático. Ao Delegado ou à Delegada de Polícia incumbe zelar por essa superioridade ética, tornando-se, assim, figuras relevantes na promoção da dignidade humana e, consequentemente, da justiça.

No que tange especificamente à sua relação com a mídia, uma importante ilação deve ser feita: a notícia não apenas reproduz a realidade, ela também tem o condão de nela influir. E o faz por dois mecanismos: a seleção dos fatos que serão divulgados e o enquadramento que se dará aos mesmos.

É interessante notar que, quando a notícia é o crime, a autoridade policial tem papel crucial na seleção do que será divulgado, de modo que também ela passa a influenciar a construção da realidade criminológica. ${ }^{73} \mathrm{E}$ se o primeiro ponto de vista sobre o desviante e os fatos por ele supostamente cometidos será aquele fornecido pela autoridade policial ao jornalista, sua responsabilidade pela garantia dos direitos fundamentais dessa pessoa torna-se evidente.

A Autoridade Policial deve, pois, impedir que a imagem do desviante detido seja divulgada pela mídia. Os atos de investigação criminal não são minuciosamente previstos no regramento processual penal. $\mathrm{O}$ art. $6^{\circ}$ do Código de Processo Penal apenas exemplifica diligências que podem ser realizadas pela Autoridade Policial na condução do inquérito.

Não poderia ser diferente, na medida em que cada crime possui peculiaridades que demandarão diferentes abordagens na sua elucida-

71 CASARA, Rubens. Processo Penal do Espetáculo. Ensaios sobre o Poder Penal, a Dogmática e o Autoritarismo na Sociedade Brasileira. Florianópolis: Empório do Direito, 2015. p. 17.

72 Ibidem.

73 ROCHA, Álvaro Filipe Oxley da. Mídia e Sistema Penal. In: SOUZA Bernardo de Azevedo e; SILVEIRA, Felipe Lazzari da (orgs.). Democracia e (m) Sistema Penal. Porto Alegre: Canal Ciências Criminais, 2017. p. 49. 
ção. À Autoridade Policial, cuja atuação é de natureza jurídica, cabe, na condução do inquérito, decidir os atos a realizar, bem como a ordem em que esses atos investigatórios deverão ser realizados para viabilizar a apuração das circunstâncias, da materialidade e da autoria das infrações penais ${ }^{74}$.

A regra, segundo o que se demonstrou, é a proteção da imagem do desviante preso, como medida de efetivação da dignidade da pessoa humana. Não obstante, a exposição da imagem deve ser admitida quando a elucidação de fatos criminosos ou a captura de suspeitos dela depender. Como bem diz Simone Schereiber:

O crime é um acontecimento público e a coletividade tem legítimo interesse de se manter informada e de receber e expressar opiniões sobre o fato e suas repercussões jurídicas. [...] Contudo, isso não reduz a esfera de proteção conferida a tal acusado de ser julgado sob as garantias do devido processo legal. ${ }^{75}$

Não se trata, enfim, de, por exemplo, impedir que as imagens de câmeras de segurança que captaram um crime e que podem levar à identificação de seu autor ou autora sejam divulgadas, ou que seja disponibilizado aos meios de comunicação o retrato falado de um estuprador serial. Da mesma forma, pode se mostrar relevante que o modo de agir e a imagem de um acusado de estelionato sejam apresentados à população, como mecanismo para trazer à polícia outras vítimas de seus golpes. Tal como diz Fábio Martins Andrade, este é um cenário no qual "a divulgação de notícias pelos órgãos da mídia pode transformar os membros de determinada sociedade ou comunidade local em potenciais colaboradores do trabalho policial"76. A

74 A Lei no $12.830 / 2.013$, que dispõe sobre a investigação criminal conduzida pelo Delegado ou pela Delegada de Polícia, expressamente registra que a atividade investigativa detém natureza jurídica e tem como objetivo a apuração das circunstâncias, da materialidade e da autoria das infrações penais.

75 SCHREIBER, Simone. A publicidade opressiva dos julgamentos criminais. Revista Brasileira de Ciências Criminais, São Paulo, v. 18, n. 86, p. 336-379., set./out. 2010. p. 356.

76 ANDRADE, Fábio Martins de. Mídia e Poder Judiciário: a influência dos órgãos da mídia no processo penal brasileiro. Rio de Janeiro: Lumen Juris, 2007. p. 268. 
Autoridade Policial deve, nessas condições, ponderar acerca da necessidade de exposição da imagem do desviante, tendo sempre como norte a dignidade da pessoa humana e como instrumento os princípios da proporcionalidade e razoabilidade ${ }^{77}$.

\section{CONCLUSÃO}

Vivemos tempos de insegurança e a sociedade, representada tanto quanto insuflada pela mídia e seu discurso neopositivista exacerbado, clama por medidas drásticas no combate ao crime. Tornou-se, assim, comum a apresentação de desviantes detidos ao clamor público, espetaculizando as diligências policiais nem sempre por motivos justificáveis. O suposto desviante é mostrado como troféu porque a sociedade assim o anseia.

Ocorre que a CF garante ao desviante detido, a despeito de sua conduta social inadequada ou criminosa, o respeito à dignidade, no que se insere o direito à imagem. Neste estudo questionou-se acerca da existência de circunstâncias que autorizem a apresentação do desviante à mídia.

Muito embora a dignidade humana seja um valor absoluto, não passível de relativização, o direito à imagem não pode ser encarado sob esse prisma ${ }^{78}$. Ele pode sofrer restrições no caso concreto, desde que elas sejam razoáveis e justificadas na necessidade de proteção de outro bem jurídico tutelado constitucionalmente ou de outro direito fundamental.

A apresentação da imagem do desviante detido à mídia, portanto, não pode ser vedada em caráter absoluto, sendo admissível a depen-

77 CUNHA, Luana Magalhães de Araújo. Mídia e Processo Penal: a influência da imprensa nos julgamentos dos crimes dolosos contra a vida à luz da Constituição de 1988. Revista Brasileira de Ciências Criminais, São Paulo, v. 94, p. 199-237., jan./fev. 2012.

78 "O direito à imagem [...] não é absoluto e frequentemente entra em linha de colisão com outros direitos fundamentais, com destaque [...] para a liberdade de expressão." (SARLET. Ingo Wolfgang; MARINONI, Luiz Guilherme; MITIDIERO, Daniel. Curso de Direito Constitucional. $2^{\text {a }}$ Ed. São Paulo: Revista dos Tribunais, 2013. p. 441). 
der das circunstâncias do caso concreto. A participação da sociedade pode se mostrar necessária, como se demonstrou.

A limitação será sempre a proporcionalidade, ponderando-se que o princípio da presunção de inocência deverá ser considerado quando se cogitar de exposição da figura do desviante detido. Não se pode olvidar, entretanto, que em havendo dúvidas a respeito da legitimidade da exposição, a dúvida deverá militar em favor do desviante. ${ }^{79}$

O Delegado ou a Delegada de Polícia são a primeira autoridade estatal investida do poder-dever de zelar pela razoabilidade da exposição do desviante. E, como integrantes do sistema de garantias constitucionais fundamentais, não se podem deixar influenciar pela opinião pública. A ele/ela é dado decidir, segundo a conveniência da investigação, e, sobretudo, sob a égide do princípio da dignidade da pessoa humana, acerca da eventual possibilidade de exposição da imagem do suposto desviante ${ }^{80}$, pautando-se por um agir democrático, que deve resistir às pressões midiáticas e sociais, atuando, se for o caso, na contramão do discurso midiático, sem se curvar aos que o criticam por assumir um papel mais garantista na sua atividade.

\section{RefERÊNCIAS BIBLIOGRÁFICAS}

ANDRADE, Fábio Martins de. Mídia e Poder Judiciário: a influência dos órgãos da mídia no processo penal brasileiro. Rio de Janeiro: Lumen Juris, 2007.

BATISTA, Nilo. Mídia e sistema penal no capitalismo tardio. Disponível em: $<$ http://www.bocc.ubi.pt/pag/batista-nilo-midia-sistema-penal.pdf $>$. Acesso em: 03 mai. 2017.

BARATTA, Alessandro. Criminologia Crítica e Crítica do Direito Penal: introdução à sociologia do direito penal. Rio de Janeiro: Editora Revan: Instituto Carioca de Criminologia, 2002.

79 Nicolas Gonzales-Cuellar Serrano, ao discorrer sobre a proporcionalidade esclarece que o princípio também deve viger em processo penal, tendo em vista a gravidade dos intereses nele em conflito: a liberdade do desviante e o jus puniendi (GONZALEZ-CUELLAR SERRANO, Nicolas. Proporcionalidad y Derechos Fundamentales en el Proceso Penal. Madrid: Colex, 1990. p. 17).

80 A decisão pela exposição da imagem do preso deve, obviamente, ser fundamentada, de modo a viabilizar adequado controle de sua atuação e eventual responsabilização na hipótese de configuração de abuso de autoridade. 
BELLI, Benoni. Tolerância Zero e Democracia no Brasil: visões da segurança pública na década de 90. São Paulo: Ed. Perspectiva, 2004.

BITENCOURT, Cezar Roberto; BITENCOURT, Vania Barbosa Adorno. Em dia de terror, Supremo rasga a Constituição no julgamento de um HC. Consultor Jurídico, 18/2/2016, in http://www.conjur.com.br/2016-fev-18/cezar-bittencourt-diaterror-stf-rasga-constituicao. Acesso em: 20 fev. 2016.

BERTRAND, Claud-Jean. O Arsenal da Democracia: sistemas de responsabilização da mídia. Bauru: EDUSC, 2002.

BRANCO, Paulo Gustavo Gonet; MENDES, Gilmar Ferreira. Curso de Direito Constitucional. 6a Ed. São Paulo: Saraiva, 2011.

BOLDT, Raphael. Criminologia Midiática: do discurso punitivo à corrosão simbólica do garantismo. Curitiba: Juruá, 2013.

CANOTILHO, José Joaquim Gomes. Direito Constitucional. $7^{\mathrm{a}}$ Ed. Coimbra: Almedina, 2003.

CASARA, Rubens R. R. Processo Penal do Espetáculo. Ensaios sobre o Poder Penal, a Dogmática e o Autoritarismo na Sociedade Brasileira. Florianópolis: Empório do Direito, 2015.

CASARA, Rubens R. R. Mitologia Processual Penal. São Paulo: Saraiva, 2015.

CHAMPAGNE, Patrick. Formar a opinião. O novo jogo político. Petrópolis: Vozes, 1998.

CHARAUDEAU, Patrick. Discurso das Mídias. São Paulo: Contexto, 2006.

CUNHA, Luana Magalhães de Araújo. Mídia e Processo Penal: a influência da imprensa nos julgamentos dos crimes dolosos contra a vida à luz da Constituição de 1988. Revista Brasileira de Ciências Criminais, São Paulo, v. 94, p. 199-237., jan./fev. 2012.

CRUZ, Rogério Schietti Machado. Rumo a um Processo Penal Democrático. In: MACHADO, Bruno Amaral (coord.). Justiça Criminal e Democracia. Madrid/ Barcelona/Buenos Aires/São Paulo: Marcial Pons - Fundação Escola Superior do Ministério Público do Distrito Federal e Territórios, 2013. p. 23-58.

DIEL, Aline Ferreira da Silva; WERMUTH, Maiquel Angelo Dezordi. Desvelando o Arauto: mídia, crime e direitos humanos em tempos difíceis. In: SOUZA Bernardo de Azevedo e; SILVEIRA, Felipe Lazzari da (orgs.). Democracia e $(m)$ Sistema Penal. Porto Alegre: Canal Ciências Criminais, 2017. p. 38-47.

FARIAS, Paulo José Leite. Ordem Urbanística e a Prevenção da Criminalidade. Revista de Informação Legislativa. Brasília, a 42 n. 168 out/dez/2005. 
FERNANDES, Antonio Scarance. Processo Penal Constitucional. $7^{\text {a }}$ Ed. São Paulo: Revista dos Tribunais, 2012.

FERRAJOLI, Luigi. Justicia Penal y Democracia. Jueces para La Democracia, n. 4, Madrid, set./1988.

GIACOMOLLI, Nereu J. Qualidade do Inquérito Policial. In: AMBOS, Kai; MALARINO, Ezequiel; VASCONCELOS, Eneas Romero. (orgs). Polícia e Investigação no Brasil. Brasília: Gazeta Jurídica, 2016. p. 153-181.

GOMES, Marcus Alan de Melo. Mídia e Sistema penal: as distorções da criminalização nos meios de comunicação. Rio de Janeiro: Revan, 2015.

GONZALEZ-CUELLAR SERRANO, Nicolas. Proporcionalidad y Derechos Fundamentales en el Proceso Penal. Madrid: Colex, 1990.

GUARESCHI, Pedrinho A. BIZ, Osvaldo. Mídia \& Democracia. Porto Alegre: PG/ OB, 2005.

KELLING, George L.; WILSON, James Q. Broken Windows. The Police and neighborhood safety. Disponível em: <http://www.theatlantic.com/magazine/ archive/1982/03/broken-windows/304465/>. Acesso em: 4 mai. 2017

LLOSA, Mario Vargas. A Civilização do Espetáculo. Uma radiografia do nosso tempo e da nossa cultura. Rio de Janeiro: Objetiva, 2013.

LOPES JÚNIOR, Aury; BADARÓ, Gustavo Henrique. Parecer: Presunção de Inocência: do conceito de trânsito em julgado da sentença penal condenatória. Disponível em: <http://emporiododireito.com.br/wpcontent/ uploads/2016/06/Parecer_Presuncao_de_Inocencia_Do_concei.pdf >. Acesso em: 30 jan. 2017

LOPES Jr., Aury; GLOECKNER, Ricardo Jacobsen. Investigação Preliminar no Processo Penal. São Paulo: Saraiva, 2014.

MACHADO, Leonardo Marcondes. Investigação Preliminar: por uma política de redução de dor. In: KHALED JR. Salah H. (coord.). Sistema Penal e Poder Punitivo. Estudos em homenagem ao Prof. Aury Lopes Jr. Florianópolis: Empório do Direito, 2015. p. 333-343.

MIRANDA, Jorge. A Dignidade da Pessoa Humana e a Unidade Valorativa do Sistema de Direitos Fundamentais. In: MIRANDA, Jorge; SILVA, Marco A. (coord.). Tratado Luso-Brasileiro da Dignidade Humana. São Paulo: Quartier Latin, 2008.

MORETZSOHN, Sylvia. Jornalismo em "tempo real": o fetiche da velocidade. Rio de Janeiro: Revan, 2002. 
NUCCI, Guilherme de Souza. Manual de Processo Penal e Execução Penal. $12^{\mathrm{a}}$ Ed. Rio de Janeiro: Forense, 2015.

OLIVEIRA, Luciano. Manual de Sociologia Jurídica. Petrópolis: Vozes, 2015.

PASTANA, Débora Regina. Cultura do Medo: reflexões sobre violência criminal, controle social e cidadania no Brasil. São Paulo: Método, 2003.

PENA, Felipe. Teoria do Jornalismo. São Paulo: Contexto, 2005.

ROCHA, Álvaro Filipe Oxley da. Mídia e Sistema Penal. In: SOUZA Bernardo de Azevedo e; SILVEIRA, Felipe Lazzari da (orgs.). Democracia e(m) Sistema Penal. Porto Alegre: Canal Ciências Criminais, 2017. p. 49.

ROSA, Alexandre Morais da. A Teoria dos Jogos Aplicada ao Processo Penal. $2^{\mathrm{a}}$ Ed. Florianópolis: Rei Livros, 2015.

SARLET, Ingo Wolfgang; MARINONI, Luiz Guilherme; MITIERO, Daniel. Curso de Direito Constitucional. $2^{\text {a }}$ Ed. São Paulo: Revista dos Tribunais, 2013.

SARLET, Ingo Wolfgang. Direitos fundamentais viveram série de retrocessos no plano fático e jurídico. Disponível em: <http://www.conjur.com.br/2016dez-30/retrospectiva-2016-direitos-humanos-viveram-serie-retrocessos $>$. Acesso em: 12 jan. 2017.

SCHREIBER, Simone. A publicidade opressiva dos julgamentos criminais. Revista Brasileira de Ciências Criminais, São Paulo, v. 18, n. 86, p. 336-379., set./ out. 2010.

VALENTE, Manuel Monteiro Guedes. A Polícia do Estado Democrático e de Direito. Florianópolis: Empório do Direito, 2015.

WACQUANT. Loïc. As Prisões da Miséria. Rio de Janeiro: Jorge Zahar Editor, 2001.

ZAFFARONI, Eugênio Raúl. Poder Judiciário. Crise, acertos e desacertos. Trad. Juarez Tavarez. São Paulo: RT, 1995.

ZAFFARONI, Eugênio Raúl. O Inimigo no Direito Penal. Rio de Janeiro: Editora Revan: Instituto Carioca de Criminologia, 2007.

ZAFFARONI, Eugênio Raúl. A Palavra dos Mortos. Conferências de Criminologia Cautelar. São Paulo: Saraiva, 2012. 


\section{DADOS DO PROCESSO EDITORIAL}

(http://www.ibraspp.com.br/revista/index.php/RBDPP/about/editorialPolicies)

- Recebido em: 27/03/2017

- Controle preliminar e verificação de plágio: 28/03/2017

- Avaliação 1: 29/03/2017

- Avaliação 2: 10/04/2017

- Avaliação 3: 13/04/2017

- Decisão editorial preliminar: 14/04/2017

- Retorno rodada de correções 1: 02/05/2017

- Decisão editorial preliminar 2: 03/05/2017

- Retorno rodada de correções 2: 07/05/2017

- Decisão editorial final: 08/05/2017

\section{Equipe editorial envolvida}

- Editor-chefe: 1 (VGV)

- Editor-associado: 1 (MMGV)

- Revisores: 3

\section{COMO CITAR ESTE ARTIGO:}

MENDES, Soraia R.; BURIN, Patrícia T. Na contramão do discurso midiático: uma perspectiva garantista da atuação do Delegado ou da Delegada de Polícia. Revista Brasileira de Direito Processual Penal, Porto Alegre, vol. 3, n. 2, p. 537-566, mai./ago. 2017. https://doi.org/10.22197/rbdpp.v3i2.66

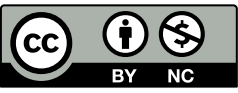

Esta obra está licenciada com uma Licença Creative Commons Atribuição-NãoComercial 4.0 Internacional. 